\title{
Aktivitas Antibakteri Bacillus yang Berasosiasi dengan Landak Laut di Pantai Mentigi, Lombok Barat
}

\author{
Antibacterial Activity of Sea Urchin-Associated Bacillus in Mentigi Beach, West Lombok \\ Bambang Fajar Suryadi ${ }^{1 *}$ dan Novi Febrianti ${ }^{2}$ \\ ${ }^{1}$ Program Studi Biologi Fakultas MIPA Universitas Mataram \\ Jl. Majapahit No. 62, Mataram 83125 NTB \\ ${ }^{2}$ Program Studi Pendidikan Biologi FKIP Universitas Ahmad Dahlan \\ Jl. Prof. Dr. Soepomo, Janturan, Yogyakarta \\ E-mail: bambangfs_mail@yahoo.com*Penulis untuk korespondensi
}

\begin{abstract}
The search for new antimicrobial agents is very significant. The prevalence of antimicrobial resistance among key microbial pathogens is increasing at an alarming rate worldwide. Bacillus species produce many kinds of antibiotics which share a full range of antimicrobial activities. The aim of this research is to study antibacterial activity of three bacillus isolates $(1 \mathrm{~A}, 2 \mathrm{~J}, 3 \mathrm{~L})$ which were isolated in Mentigi Beach, West Lombok. Assessment for antibacterial activity was conducted using Overlaid Molten agar method on Nutrient Agar medium at different salinity (concentration of $\mathrm{NaCl} 0,5,10 \%$ ) and different $\mathrm{pH}(\mathrm{pH} \mathrm{6,7}$ and 8). The study showed that there were different antibacterial activities at different salinity and different $\mathrm{pH}$ media. Production of antibacterial at $0 \% \mathrm{NaCl}$ concentration occurred only at $\mathrm{pH} 6$ and 7 and had narrow spectrum character (only for Gram positive bacteria). Addition of 5\% $\mathrm{NaCl}$ made antibacterial production might occur at $\mathrm{pH} \mathrm{6,7}$ and 8 and had wide spectrum character (for Gram positive and negative bacteria).
\end{abstract}

Key words: Antibacterial, Bacillus, sea urchin

\begin{abstract}
Abstrak
Pencarian senyawa antibiotik baru merupakan hal yang sangat penting. Meratanya resistensi terhadap senyawa antimikrobia pada mikrobia-mikrobia patogen kunci mengalami peningkatan dengan kecepatan yang membahayakan di seluruh dunia. Spesies-spesies Bacillus menghasilkan bermacam-macam antibiotik yang mempunyai kisaran aktivitas antimikrobia yang luas. Tujuan penelitian ini adalah mempelajari aktivitas antimikrobia tiga isolat Bacillus (1A, 2J, 3L) yang diisolasi dari Pantai Mentigi, Lombok Barat. Pengujian aktivitas antibakteri dilakukan dengan menggunakan metode Overlaid molten agar pada medium nutrient agar dengan salinitas yang berbeda (konsentrasi $\mathrm{NaCl} 0,5,10 \%)$ dan $\mathrm{pH}$ yang berbeda $(\mathrm{pH} \mathrm{6,7,8)}$. Hasil penelitian menunjukkan terjadi perbedaan aktivitas antibakteri pada salinitas dan $\mathbf{p H}$ medium yang berbeda. Produksi antibakteri pada konsentrasi $\mathrm{NaCl} 0 \%$ terjadi hanya pada $\mathrm{pH}$ 6 dan 7 dan mempunyai spektrum antibakteri yang sempit (hanya untuk bakteri Gram positif). Penambahan 5\% NaCl membuat produksi antibakteri terjadi pada $\mathrm{pH} 6$, 7, dan 8 dan mempunyai karakter spektrum yang luas (untuk bakteri Gram positif dan negatif).
\end{abstract}

Kata kunci: Antibakteri, Bacillus, landak laut

Diterima: 04 Desember 2009, disetujui: 10 Maret 2010

\section{Pendahuluan}

Meningkatnya penggunaan antibiotik mengakibatkan terjadinya peningkatan resistensi mikrobia patogen terhadap senyawa tersebut. Resistensi ini dapat terjadi karena berbagai faktor, antara lain mutasi, transfer bahan genetik dan juga evolusi mikrobia patogen itu sendiri. Solusi yang dapat dilakukan antara lain dengan penggunaan antibiotik yang lebih rasional dan juga pencarian antibiotik baru. Antibiotik alami merupakan sumber antibiotik yang dapat terus dieksplorasi. Produk alami mikrobia merupakan sumber antibiotik yang terbesar saat ini dan 
paling memberi harapan untuk masa yang akan datang (Pelaez, 2005 dan Sidharta, 2003).

$$
\text { Spesies-spesies Bacillus banyak }
$$

menghasilkan senyawa antibiotik. Antibiotik yang dihasilkan Bacillus biasanya berupa senyawa peptida, antara lain basitrasin, gramisidin, sirkulin dan polimiksin. Bacillus penghasil antibiotik tersebut kebanyakan diisolasi dari tanah (Yilmaz et al., 2005; Aslim et al., 2002). Sebenarnya Bacillus merupakan kelompok bakteri yang dapat hidup pada berbagai tipe habitat, oleh sebab itu perlu dilakukan pencarian strain baru Bacillus penghasil antibiotik dari sumber-sumber yang baru. Diharapkan akan didapatkan senyawa antibiotik baru dari sumber-sumber baru tersebut.

Provinsi Nusa Tenggara Barat, khususnya pulau Lombok memiliki wilayah laut yang sangat luas. Luas wilayah laut NTB mencapai 29 ribu kilometer persegi atau sekitar 59,13 persen dari luas wilayah NTB secara keseluruhan. Kekayaan sumberdaya hayati yang dimiliki sangat beragam, termasuk kekayaan jenis-jenis mikrobia yang hidup di laut. Tresnani dan Febrianti (2006) berhasil mengisolasi lima isolat bakteri yang bersimbiosis dengan landak laut di pantai Mentigi, Kabupaten Lombok Barat. Penelitian lebih lanjut berhasil mengidentifikasi kelima isolat bakteri tcrsebut merupakan anggota dari genus Bacillus (Febrianti dan Tresnani, 2007).

Mikroba laut merupakan penghasil senyawa bioaktif baru yang dapat diaplikasikan dalam industri farmasi. Banyak senyawa antibiotik yang selama ini diperkirakan dihasilkan oleh invertebrata laut ternyata diproduksi oleh mikrobia simbionnya (Hunter-Cevera et al., 2005; Zhang et al., 2005). Antibiotik yang dihasilkan oleh mikrobia laut mempunyai kemampuan antimikrobia yang tinggi (Pelaez et al., 2005). Burkholder et al., 1966 dan Lemos et al., 1985 dalam Austin (1992) mendapatkan isolat bakteri Pseudomonas broumotilis dan Alteromonas yang mempunyai aktivitas antibakteri dari berbagai jenis rumput laut. Isnansetyo dan Kamei (2003) menemukan beberapa bakteri laut yang menghasilkan senyawa antibiotik antara lain Bacillus menghasilkan lolotin dan Pelagiobacter variabilis menghasilkan pelagiomicins.
Penelitian yang dilakukan Kanagasabhapathy et al., (2004) menemukan Bacillus yang hidup di permukaan tubuh invertebrata laut menghasilkan senyawa kimia yang memiliki potensi antibakteri.

Salinitas dan $\mathrm{pH}$ medium uji sangat memengaruhi kemampuan mikrobia untuk menghasilkan senyawa antibakteri. Penelitian yang dilakukan Vasavada et al., (2006) dan Kanagasabhapathy et al., (2004) mendapatkan bahwa terjadi perbedaan produksi senyawa antibakteri pada berbagai salinitas medium uji. Jamil et al., (2007) dan Awais et al., (2007) mendapatkan kondisi $\mathrm{pH}$ yang berbeda akan memengaruhi kemampuan optimal mikrobia untuk memproduksi senyawa antibakteri. Penelitian ini bertujuan mengetahui aktivitas antibakteri tiga isolat Bacillus yang berasosiasi dengan landak laut di pantai Mentigi Lombok Barat pada berbagai salinitas dan $\mathrm{pH}$ medium uji. Diperkirakan faktor salinitas dan $\mathrm{pH}$ medium mempunyai pengaruh yang signifikan terhadap kemampuan optimal isolat Bacillus menghasilkan senyawa antibakteri.

\section{Metode Penelitian}

\section{Isolat Bakteri}

Isolat bakteri yang diteliti adalah bakteri Bacillus yang berasosiasi dengan landak laut di Pantai Mentigi, Lombok Barat, yaitu isolat 1A, isolat $2 \mathrm{~J}$ dan isolat $3 \mathrm{~L}$. Ketiga isolat ini didapatkan dari bagian luar dan dalam tubuh landak laut. Bagian luar berupa gabungan antara cangkang dan duri dari landak laut yang dihaluskan, sedangkan bagian dalam berupa saluran pencernaan yang juga dihaluskan.

Bagian landak laut yang akan digunakan dipotong kecil dan dicuci menggunakan larutan $\mathrm{NaCl}$ fisiologis steril. Potongan organ kemudian dihaluskan menggunakan mortal yang telah disterilkan. Setelah halus kemudian ditimbang 3 gram hancuran jaringan dari landak laut dan ditambahkan $5 \mathrm{ml}$ larutan $\mathrm{NaCl}$ fisiologis steril ke dalam tabung reaksi steril.

Suspensi organ landak laut kemudian dipanaskan dalam pemanas air pada suhu $80^{\circ} \mathrm{C}$ selama 30 menit. Setelah pemanasan dilakukan pengenceran secara bertingkat $\left(\begin{array}{llll}10^{-1} & \mathrm{~s} / \mathrm{d} & 10^{-5}\end{array}\right)$ menggunakan larutan $\mathrm{NaCl}$ fisiologi steril. 
Dari masing-masing pengenceran diambil masing-masing sebanyak $100 \mu \mathrm{L}$ dan disebar pada media NA kemudian diinkubasi pada suhu $30^{\circ} \mathrm{C}$ selama $24 \mathrm{jam}$.

Koloni yang tumbuh pada cawan petri diamati morfologi selnya dengan pewarnaan Gram. Tampilan sel bakteri berbentuk batang, Gram positif, dengan atau tanpa penampakan endospora mengindikasikan bahwa sel yang tumbuh pada biakan tersebut adalah Bacillus.

\section{Medium Pertumbuhan dan Pengujian}

Medium pertumbuhan dan pengujian Bacillus adalah medium NB (Nutrien Broth) dan medium NA (Nutrien Agar). Medium disterilkan dengan autoklaf pada suhu $121^{\circ} \mathrm{C}$, tekanan 1 atm, selama 15 menit.

\section{Uji Aktivitas Antibakteri}

Uji aktivitas antibakteri dilakukan terhadap tiga isolat bakteri klinik yang bersifat Gram positif (Staphylococcus aureus, Bacillus cereus, Bacillus mycoides) dan tiga isolat bakteri klinik yang bersifat Gram negatif (Escherichia coli, Proteus mirabilis dan Klebsiella pneumoniae). Mikrobia uji ini merupakan isolat klinik yang didapatkan dari Unit Riset Biomedik - RSUD Mataram.

Pengujian aktivitas antibakteri dilakukan dengan teknik Overlaid Molten Agar. Isolat murni Bacillus disubkultur pada medium padat NA (Nutrien Agar) membentuk lingkaran dengan diameter 1,5-2 $\mathrm{cm}$ dan diinkubasi selama 48 jam pada suhu $37^{\circ} \mathrm{C}$. Pada saat yang sama, isolat murni bakteri uji disubkultur pada medium NB (Nutrient Broth) dan diinkubasi pada suhu $37^{\circ} \mathrm{C}$ selama 24 jam. Suspensi biakan sebanyak $500 \mu \mathrm{L}$ dari medium NB ditambahkan dengan $1,5 \mathrm{~mL}$ medium agar semisolid (konsentrasi agar $10 \mathrm{~g} / \mathrm{L}$ ), kemudian diaduk dengan pipet steril hingga homogen. Campuran ini kemudian dituangkan secara merata pada biakan Bacillus yang berusia 48 jam, ditunggu hingga memadat dan diinkubasi kembali pada suhu $37^{\circ} \mathrm{C}$ selama 48 jam. Pengamatan zona penghambatan pertumbuhan dilakukan tiap 6 jam selama 48 jam. Hal ini dikarenakan pada uji pendahuluan diketahui bahwa kemampuan isolat-isolat Bacillus untuk membentuk zona penghambatan terjadi dalam waktu yang bervariasi selama kurun 48 jam.
Pengujian aktivitas antibakteri dilakukan dengan memberi tiga variasi salinitas medium uji, yaitu kadar $\mathrm{NaCl} 0,5$ dan $10 \%$. Pada tiaptiap salinitas tersebut dibuat variasi $\mathrm{pH}$ awal medium, yaitu 6, 7 dan $\mathrm{pH} 8$.

Penelitian ini merupakan penelitian awal untuk mengetahui aktivitas antibakteri tiga isolat Bacillus yang berasosiasi dengan landak laut. Variasi perlakuan salinitas dan $\mathrm{pH}$ dilakukan sebagai upaya optimasi untuk mendapatkan isolat Bacillus yang mampu menghasilkan senyawa antibakteri.

\section{Hasil dan Pembahasan}

Pada kadar $\mathrm{NaCl} 0 \%$ (Tabel 1), penghambatan pertumbuhan bakteri uji hanya terjadi pada $\mathrm{pH} 6$ dan 7. Pada $\mathrm{pH} 6$ isolat $1 \mathrm{~A}$ mampu membentuk zona hambatan terhadap ketiga jenis bakteri uji Gram negatif dan satu bakteri uji Gram positif. Pada $\mathrm{pH} \mathrm{7,} \mathrm{isolat} \mathrm{1A}$ dan isolat 3L mampu membentuk zona hambatan masing-masing terhadap B. mycoides dan E. coli. Tidak ada isolat bakteri yang mampu membentuk zona hambatan terhadap bakteri uji pada $\mathrm{pH}$ 8. Zona hambatan terbesar pada kadar $\mathrm{NaCl} 0 \%$ terbentuk pada $\mathrm{pH}$ 6, yaitu sebesar 23 $\mathrm{mm}$ yang dihasilkan oleh isolat 1A terhadap bakteri uji S. aureus.

Aktivitas penghambatan keseluruhan isolat Bacillus pada kadar $\mathrm{NaCl} 0 \%$ ini dapat diamati mulai jam ke-20 inkubasi dan dapat diamati lebih dari 24 jam. Spektrum penghambatan isolat $1 \mathrm{~A}$ dan $3 \mathrm{~L}$ sempit karena lebih cenderung membentuk zona hambatan terhadap bakteri Gram negatif saja.

Pada kadar $\mathrm{NaCl} 5 \%$ (Tabel 2) ketiga isolat menunjukkan kemampuan yang lebih bervariasi dalam membentuk zona hambatan. Pada pH 6 ketiga isolat mampu menghambat pertumbuhan terhadap $S$. aureus. Pada $\mathrm{pH}$ ini isolat $2 \mathrm{~J}$ dan $3 \mathrm{~L}$ juga mampu menghambat pertumbuhan bakteri Gram positif $B$. cereus dan B. mycoides. Pada $\mathrm{pH} 7$ isolat $2 \mathrm{~J}$ dan $3 \mathrm{~L}$ mampu membentuk zona hambatan terhadap berbagai jenis bakteri uji. Pada $\mathrm{pH} 8$, isolat $2 \mathrm{~J}$ dan $3 \mathrm{~L}$ juga mampu membentuk zona hambatan pada E. coli, $K$. pneumoniae dan $P$. mirabilis yang ketiganya merupakan bakteri Gram negatif. Zona hambatan terbesar pada kadar $\mathrm{NaCl} 5 \%$ terbentuk pada $\mathrm{pH}$ 
7, yaitu sebesar $34 \mathrm{~mm}$ yang dihasilkan oleh isolat 3L terhadap bakteri uji B. cereus.

Aktivitas penghambatan ketiga isolat Bacillus pada kadar $\mathrm{NaCl} 5 \%$ ini terjadi pada ketiga variasi $\mathrm{pH}$ yang diujikan. Penghambatan mulai dapat diamati pada jam ke-20 inkubasi dan dapat diamati lebih dari 24 jam. Spektrum penghambatan yang dihasilkan luas karena dapat menekan pertumbuhan bakteri Gram positif dan Gram negatif.

Pengujian aktivitas antibakteri pada kadar $\mathrm{NaCl} 10 \%$ menunjukkan tidak ada isolat Bacillus yang mampu membentuk zona hambatan terhadap seluruh bakteri uji.

Tabel 1. Diameter zona hambatan yang dibentuk oleh tiga isolat pada kadar $\mathrm{NaCl} 0 \%$.

\begin{tabular}{|c|c|c|c|c|}
\hline \multirow[t]{2}{*}{ pH Medium Uji } & \multirow[t]{2}{*}{ Bakteri Uji } & \multicolumn{3}{|c|}{ "Diameter zona Hambat (dalam mm) } \\
\hline & & Isolat 1A & Isolat 2J & Isolat 3L \\
\hline \multirow[t]{6}{*}{ 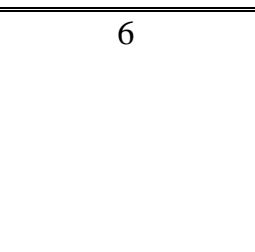 } & B. cereus & 16 & (2 & - \\
\hline & B. mycoides & 17 & - & - \\
\hline & S. aureus & 23 & - & - \\
\hline & E. coli & 11 & - & - \\
\hline & K. pneumoniae & - & - & - \\
\hline & P. mirabilis & - & - & - \\
\hline \multirow[t]{6}{*}{7} & B. cereus & - & - & - \\
\hline & B. mycoides & 20 & - & - \\
\hline & S. aureus & - & - & - \\
\hline & E. coli & - & _ & 12 \\
\hline & K. pneumoniae & - & - & - \\
\hline & P. mirabilis & - & - & - \\
\hline \multirow[t]{6}{*}{8} & B. cereus & - & - & - \\
\hline & B. mycoides & - & - & - \\
\hline & S. aureus & - & - & - \\
\hline & E. coli & - & - & - \\
\hline & K. pneumoniae & - & - & - \\
\hline & P. mirabilis & - & - & - \\
\hline
\end{tabular}

Tabel 2. Diameter zona hambatan yang dibentuk oleh tiga isolat Bacillus pada kadar $\mathrm{NaCl} 5 \%$.

\begin{tabular}{|c|c|c|c|c|}
\hline \multirow{2}{*}{ pH Media Uji } & \multirow{2}{*}{ Bakteri Uji } & \multicolumn{3}{|c|}{ Diameter zona hambat (dalam mm) } \\
\hline & & Isolat 1A & Isolat 2J & Isolat 3L \\
\hline \multirow[t]{6}{*}{6} & B. cereus & & - & - \\
\hline & B. mycoides & & - & - \\
\hline & S. aureus & 18 & 19 & 16 \\
\hline & E. coli & - & - & - \\
\hline & K. pneumoniae & - & - & - \\
\hline & P. mirabilis & - & - & - \\
\hline \multirow[t]{6}{*}{7} & B. cereus & - & - & 34 \\
\hline & B. mycoides & - & 14 & 23 \\
\hline & S. aureus & - & - & - \\
\hline & E. coli & - & 11 & - \\
\hline & K. pneumoniae & - & - & 18 \\
\hline & P. mirabilis & - & - & - \\
\hline \multirow[t]{6}{*}{8} & B. cereus & - & - & - \\
\hline & B. mycoides & - & - & - \\
\hline & S. aureus & - & - & - \\
\hline & E. coli & - & 11 & 15 \\
\hline & K. pneumoniae & - & - & 18 \\
\hline & P. mirabilis & - & 13 & 14 \\
\hline
\end{tabular}


Salinitas medium uji mempengaruhi kemampuan isolat Bacillus untuk memproduksi senyawa antibakteri. Pada medium uji dengan kondisi tawar (salinitas 0\%) isolat-isolat Bacillus mampu menghasilkan senyawa antibakteri. Hasil yang sama ditunjukkan oleh penelitian Kanagasabhapathy et al., (2004) yang mendapatkan aktivitas antibakteri pada bakteri yang berasosiasi dengan sponge yang ditumbuhkan pada medium dengan salinitas $0 \%$. Hal ini merupakan fenomena yang cukup menarik karena isolat bakteri pada kedua penelitian ini didapat dari invertebrata yang hidup di laut.

Kemampuan maksimal produksi senyawa antibakteri terjadi pada medium uji yang mempunyai salinitas 5\%. Hasil ini sejalan dengan penelitian Saha (2005) dalam Vasavada et al., (2006) pada aktinomisetes yang diisolasi dari laut yang menunjukkan bahwa produksi antibiotiknya maksimal terjadi pada salinitas medium 5\%. Kanagasabhapathy et al., (2004) yang menguji aktivitas antibakteri pada bakteri yang berasosiasi dengan "sponge" mendapatkan bahwa terjadi perbedaan produksi senyawa antibakteri pada berbagai kadar $\mathrm{NaCl}$ medium uji $(0 \%-10 \%)$ dan waktu inkubasi yang berbeda. Pengujian aktivitas antibakteri yang dilakukan oleh Vasavada et al., (2006) terhadap Streptomyces sannanensis alkalifilik toleran garam menunjukkan bahwa produksi antibiotik maksimal terjadi pada kadar $\mathrm{NaCl}$ medium uji $3 \%$ dan sedikit menurun pada kadar $\mathrm{NaCl} 5 \%$.

Pada penelitian ini tidak terlihat adanya aktivitas antibakteri terhadap seluruh bakteri uji pada medium uji yang mengandung $\mathrm{NaCl} 10 \%$. Hasil ini berlawanan dengan hasil penelitian Kanagasabhapathy et al., (2004) yang memperlihatkan adanya aktivitas antibakteri pada kadar salinitas medium uji $10 \%$. Diperkirakan tempat asal isolat dan jenis isolat bakteri yang berbeda akan membutuhkan kondisi salinitas medium uji yang berbeda untuk dapat menghasilkan senyawa antibakteri.

Variasi $\mathrm{pH}$ awal medium yang diujikan pada penelitian ini memengaruhi kemampuan isolat Bacillus dalam memproduksi senyawa antibakteri. Aktivitas antibakteri dapat diamati pada kisaran pH 6-8. Awais et al., (2007) yang meneliti aktivitas antibakteri ekstrak sel Bacillus sp mendapatkan bahwa zona hambatan maksimal yang terbentuk terjadi pada kisaran $\mathrm{pH}$
7-9. Menurut Jamil et al., (2007) perubahan pH eksternal dapat memengaruhi berbagai proses selular termasuk pengaturan biosintesis metabolit sekunder.

Pada penelitian ini, ketiga isolat Bacillus mampu membentuk zona hambatan pada berbagai jenis bakteri uji yang digunakan, sehingga diperkirakan isolat-isolat bakteri tersebut menghasilkan lebih dari satu jenis zat antibiotik. Hasil deteksi ini memberikan potensi penelitian/ekplorasi yang lebih lanjut. Hasil penelitian ini menunjukkan potensi yang besar bakteri yang berasal dari laut khususnya Bacillus yang berasosiasi dengan landak laut untuk menghasilkan senyawa antibakteri. Kanagasabhapathy et al., (2004) juga telah berhasil mendeteksi produksi senyawa antibakteri dari bakteri yang berasosiasi dengan permukaan sponge. Diperlukan penelitian lebih lanjut untuk mengidentifikasi jenis zat antibiotik yang dihasilkan oleh isolat-isolat Bacillus yang berasosiasi dengan landak laut ini dan mencari kondisi optimal untuk produksinya.

\section{Simpulan dan Saran}

\section{Simpulan}

Aktivitas antibakteri ketiga isolat Bacillus yang berasosiasi dengan landak laut bervariasi pada berbagai salinitas dan $\mathrm{pH}$ yang diujikan. Pada salinitas $\mathrm{NaCl} 0 \%$, penghambatan pertumbuhan hanya terjadi pada $\mathrm{pH} 6$ dan 7 dan bersifat spektrum sempit (khusus Gram positif). Dengan penambahan $\mathrm{NaCl} 5 \%$, penghambatan pertumbuhan dapat diamati pada $\mathrm{pH} 6,7$ dan 8 . Penghambatan pertumbuhannya bersifat spektrum luas (Gram positif dan negatif).

\section{Saran}

Penelitian ini perlu dilanjutkan untuk mendapatkan senyawa antibiotik yang murni, antara lain dengan melakukan optimasi produksi antibiotik melalui fermentasi pada media khusus dengan variasi kondisi fermentasi $(\mathrm{pH}$, suhu dan penggojokan) maupun suplementasi media fermentasi yang sesuai. Melakukan isolasi dan karakterisasi sifat antibiotik produk fermentasi Bacillus tersebut dengan beberapa teknik standar untuk mengetahui jenis senyawa antibiotik dan aktivitas yang dihasilkannya. 


\section{Ucapan Terima Kasih}

Penelitian ini dapat terselenggara berkat bantuan dana dari Proyek Hibah Bersaing Ditjen Dikti Depdiknas RI.

\section{Daftar Pustaka}

Aslim, B., Saglam, N. dan Beyatli, Y. 2002, Determination of Some Properties of Bacillus Isolated from Soil, Turk. J. Biol., 26: 41-48.

Austin, B. 1992. Marine Microbiology, Cambridge University Press, Cambridge.

Awais, M., Shah, A.L., Hamed, A. dan Hasan, F. 2007. Isolation, Identification and Optimization of Bacitracin Produced by Bacillus sp. J. Bot., 39 (4): 1303-1312.

Febrianti, N. dan Tresnani, G. 2007. Karakterisasi dan Identiflikasi Bakteri yang Bersimbiosis dengan Landak Laut di Pantai Mentigi, Kabupaten Lombok Barat, Laporan Penelitian SPP/DPP, Program Studi Biologi, Universitas Mataram, Mataram.

Hunter-Cevera, J., Karla, D. dan Buckley, M. 2005. Marine Microbial Diversity: The Key to Earth's Habitability. American Society of Microbiology, Boston.

Isnansetyo, A. dan Kamei, Y. 2003. MC21-A, a Bactericidal Antibiotic Produced by a New Marine Bacterium, Pseudoalteromonas phenolica isp.nov. $O$-BC $30^{\mathrm{T}}$, against Methicilin-Resistant Staphylococcus aureus, Antimicrobial Agents and Chemotherapy. 2: 480-488.

Jamil, B., Hasan, F., Hameed, A. dan Ahmed, S. 2007. Isolation of Bacillus subtilis $\mathrm{MH}-4$ from Soil and Its Potential of Polypeptidic Antibiotic Production, Pak. J. Pharm. Sci., 20 (1): 26-31.
Kanagasabhapathy, M., Nagata, K., Fujita, Y., Tamura, T., Okamura, H. dan Nagata, S. 2004. Antibacterial Activity of The Marine Sponges Psammapsilla purpurea: Importance of its Surface-Associated Bacteria. MTTS/IEEE Techno-Ocean, 3: 1323-1329.

Pelaez, F. 2005. The Historical Delivery of Antibiotics from Microbial Natural Products; Can History Repeat? Biochemical Pharmacology, 71, 981-990. Journal homepage: www.elsevier.com/ locate/biochempharm.

Sidharta, B.B.R. 2003. Screening of Antibiosis Activity from Green Algae (Chlorophyta) from Drini Beach, Yogyakarta: a Preliminary Study. Biota, VIII (2): 53-58.

Tresnani, G. dan Febrianti, N. 2006. Studi Awal Keanekaragaman Bakteri Patogen dan Parasit Pengganggu Pada Landak Laut di Pantai Mentigi, Kabupaten Lonbok Barat, Laporan Penelitian SPP/DPP, Program Studi Biologi, Universitas Mataram, Mataram.

Vasavada, S.H., Thumar, J.T. dan Singh, S.P. 2006. Secretion of a Potent Antibiotic by SaltTolerant and Alkaliphilic Actinomycete Streptomyces sannanensis Strain RJT-1. Current Scince, 91 (10): 1393-1397.

Yilmaz, M., Somn, H. dan Beyatli, Y. 2005. Antimicrobial Activities of Some Bacillus spp. Strains Isolated from The Soil. Microbiological Research, 161: 127-131.

Zhang, L., An, R., wang, J., Sun, N., Zhang, S., Hu, J. dan Kuai, J. 2005. Exploring Novel Bioactive Compounds from Marine Microbes, Current Opinion in Microbiology 8: 276-281. 